1GODFREY, W. E. 1966. The birds of Canada. Nat. Mus. Canada Bull. 203. $428 \mathrm{pp}$.

$2 \mathrm{HORCH}$, P. 1977. Bull. Manitoba Natur. Soc. 1(2):6-7.

3KOES, R. F. Personal communication. ${ }^{4} \mathrm{KYLE}, \mathrm{W}$. D. Personal communication. 5 LINDSAY, A. Personal communication. 6MEYERRIECKS, A. J. 1960. Comparative breeding behavior of four species of
North American herons. Publ. Nuttall Ornithol. Club 2. 158 pp

7 MOSSOP, H. 1963. Southern heron in Manitoba. Chickadee Notes 436. Winnipeg Free Press, Winnipeg. May 25, 1963.

8 MOSSOP, H. 1965. Four uncommon visitors. Chickadee Notes 544. Winnipeg Free Press, Winnipeg. June 19 , 1965.

\title{
FIRST RECORD OF KING EIDER NESTING IN MANITOBA
}

KENNETH F. ABRAHAM and FRED COOKE, Department of Biology, Queen's University, Kingston, Ontario, K7L 3N6.

The King Eider nests extensively in he North American arctic north of $0^{\circ} \mathrm{N}$ latitude and as far south as the Belcher Islands, N.W.T., and Cape Henrietta Maria, Ontario. No nesting ecords exist for Manitoba.2 4 Regular nesting along the Hudson Bay coast of Manitoba would comlete the rather disjunct nature of the reeding distribution in this outhernmost part of the species' ange. Jehl and Smith suggested that few pairs might be found nesting in he Cape Churchill region of Manitoba, however Cooke et al. isted the King Eider as a rare nigrant in the tundra area of Cape Churchill and La Pérouse Bay.21

A female King Eider was found on 0 June 1977 on a nest at La Pérouse Bay, Manitoba $\left(58^{\circ} 45^{\prime} \mathrm{N}, 94^{\circ} 30^{\prime} \mathrm{W}\right)$ in colony of Common Eiders. The nest vas located $50 \mathrm{~cm}$ above the level of he Mast River in fairly dense cover ff Salix planifolia and Betula glanulosa. The nests of four Common
Eiders and one Lesser Snow Goose were within $4 \mathrm{~m}$. The King Eider nest contained five King Eider eggs and one Common Eider egg and was visited daily until all six ducklings were hatched (10 July). Photographs of the female and nest were taken and the female was caught and banded. There is little doubt that this female was mated to a King Eider male as one was seen on 16 and 18 June and a pair was seen on 12 and 17 June in the immediate vicinity of the nest. Furthermore, the egg dimensions agree very closely with those given by Palmer for King Eiders (mean of our 5-egg clutch: length $64.4 \pm 1.9 \mathrm{~mm}$; width $42.5 \pm$ $0.1 \mathrm{~mm}){ }^{3}$ The Common Eider egg in the nest was quite likely the result of parasitic egg laying by that species (in 1976 and 1977 Common Eider eggs were also found in Snow Goose nests). Although the parasitic egg hatched, it was the last to do so and the duckling was still damp and 
lethargic when the King Eiders were fluffy and active in and around the nest site.

Although King Eiders are not common at La Pérouse Bay, sightings have been made each summer since 1975. Additionally, several sightings were made near Cape Churchill in June 1977 and a male King Eider in the vicinity of an eider nest (species unknown) joined the female after she was flushed (A. Didiuk, pers comm). King Eiders nesting in such low numbers could easily be overlooked, especially if observers were present after the males had departed for their moult, and/or if the nest were located amongst many nests of Common Eider as this one was. If such regular nesting is occurring, habitat com- petition with the abundant, earlie nesting Common Eider (and perhap the several nesting species of dab bling ducks) may prevent King Eider from being more numerous.

1 COOKE, F., R. K. ROSS, R. K. SCHMIDT and A. J. PAKULAK. 1975. Birds of the tundra biome at Cape Churchill and La Pérouse Bay. Canadian Field Naturalist 89(4):413-422.

2JEHL, J. R. and B. A. SMITH. 1970. Birds of the Churchill Region, Manitoba Manitoba Mus. Of Man and Nature Winnipeg, Spec. Publ. 1. 87 pp.

3PALMER, R. S. 1976. Handbook of North American birds. Volume 3. Yale University Press, New Haven. 560 pp.

${ }^{4}$ SALT, W. R. and J. R. SALT. 1976. The birds of Alberta. Hurtig Publishers. Edmonton. 498 pp.

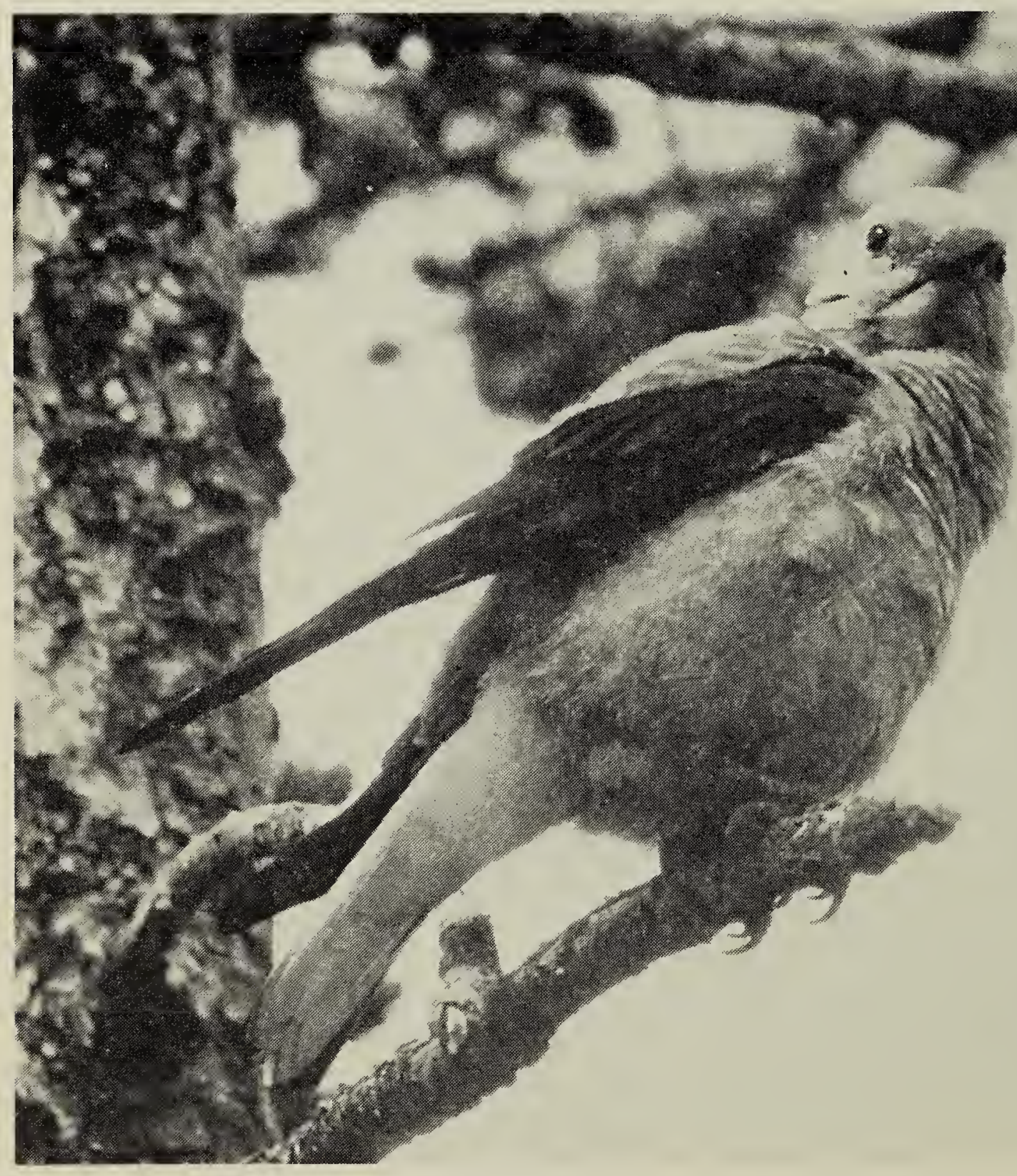

Clark's Nutcracker.

Gary W. Seib 